\title{
Potential of Azadirachta indica as a green corrosion inhibitor against mild steel, aluminum, and tin: a review
}

\author{
Sanjay K. Sharma ${ }^{1 *}$, Anjali Peter ${ }^{1}$ and Ime Bassey Obot $^{2}$
}

\begin{abstract}
Azadirachta indica (AZI, commonly recognized as "Neem") is noteworthy both for its chemical and for its biological actions. It is one of the most fruitful sources of secondary metabolites in nature. To date, more than 300 natural products have been isolated from different sections of the tree, with new compounds added to the list every year. As a contribution to the current interest on green corrosion inhibitors, the present study aims at broadening the application of plant extracts for metallic corrosion inhibition by investigating the inhibiting properties of $A$. indica especially for mild steel, aluminum, and tin. In the present article, we discuss the potential of AZI extract as a corrosion inhibitor on metal surfaces, especially of mild steel, aluminum, and tin. The adsorption isotherm studies, chemical composition of AZI, effect of temperature on inhibition efficiency and computational analysis related with AZI adsorption on metals have also been discussed in detail. This work will further help in the understanding of the adsorption mechanism involved and hence inhibition effect of plant extract against metal corrosion.
\end{abstract}

Keywords: Green chemistry; Azadirachta indica; Corrosion; Green corrosion inhibitors; Computational calculations

\section{Review}

Introduction

"Green chemistry" provides an opportunity to design any research in non-polluting way with minimum production of waste and minimum consumption of energy. It is a philosophy which is equally applicable in all fields wherever chemistry involves (Sharma et al. 2010a; Sharma et al. 2011; Sharma et al. 2009a; Linthorst 2010). "Corrosion" is a phenomenon where chemistry helps to explain its mechanism and role of ions and energy behind it. It is simply a destruction of materials resulting from an exposure and the interaction with the environment. One of the latest and popular approaches is the use of substances called corrosion inhibitor. These inhibitor molecules consist ofheterocyclic compounds with polar functional groups (e.g. N, S, O, and $\mathrm{P})$ and conjugated double bonds with different aromatic system. Basically, these substances adsorb on the metal surface to block the destruction reaction with

\footnotetext{
*Correspondence: sk.sharmaa@outlook.com

${ }^{1}$ Green Chemistry and Sustainability Research Group, Department of

Chemistry, JECRC University, Jaipur 303905, India

Full list of author information is available at the end of the article
}

aggressive media. They are both physically and chemically active adsorbate type substances (Thompson et al. 2007; Buchweishaija 2009). It is a major problem that must be confronted for safety, environmental, and economic reasons in various chemical, mechanical, metallurgical, biochemical, and medical engineering applications and more specifically, in the design of a much more varied number of mechanical parts which equally vary in size, functionality, and useful lifespan. Corrosion attack can be prevented by various methods such as materials improvement, combination of production fluids, process control, and chemical inhibition. Among these methods, the implementation of corrosion inhibition is the most excellent approach to avoid disastrous destruction of metals and alloys in corrosive media. The use of corrosion inhibitors is the most economical and convenient technique to control corrosive attack on metals. Corrosion inhibitors are chemicals either synthetic or natural which, when added in small amounts to an environment, decrease the rate of attack by the environment on metals. A number of synthetic compounds are known to be applicable as good corrosion inhibitors for metals (Quraishi et al. 2012; Kabanda et al. 2012a; Ebenso et al. 2012a). The 
importance of a corrosion study depend in the fact that corrosion causes great loses to our economy and is a major threat for human safety. Corrosion costs worldwide are therefore on the order of US\$552 billion (Chauhan and Gunasekaran 2007; Schmitt et al. 2009a). Even countries like India is suffering badly due to this problem of corrosion (Sharma and Sharma 2011). Several efforts have been made using corrosion-preventive practices, and the use of green corrosion inhibitors is one of them (Anuradha et al. 2008; Mudhoo and Sharma 2010; Sharma et al. 2010b; Sharma et al. 2010c; Aboia and James 2010; Sharma et al. 2009b; Sharma et al. 2009c). On the other hand, the attractiveness and utilization of synthetic compounds as a corrosion inhibitor has come under severe criticism due to the harsh environmental regulations and toxic effects of synthetic compounds on human and animal life. Consequently, there exists the need to build up a new class of corrosion inhibitors with low toxicity, ecofriendliness, and good efficiency. Throughout the ages, plants have been used by human beings for their basic needs such as assembly of food stuffs, shelters, clothing, fertilizers, flavors and fragrances, medicines, and last but not least, as corrosion inhibitors (Ajmal et al. 1994; Bentiss et al. 2002). The use of natural products as corrosion inhibitors can be traced back to the 1930s when plant extracts of Chelidonium majus (Celandine) and other plants were used for the first time in $\mathrm{H}_{2} \mathrm{SO}_{4}$ pickling baths (Sanyal 1981). After then, interest in using natural products as corrosion inhibitors increased substantially and scientists around the world reported several plant extracts as promising green anticorrosive agents (Schmitt et al. 2009b). Most of the gums were also reported as good corrosion inhibitor due to their gum-metal complex forming capacity, availability of $\Pi$-electrons and hetero atoms, and less toxic properties (Peter et al. 2015). The adsorption of organic molecules depends on the presence of $\Pi$ electrons and hetero atoms (Jin et al. 2006; Raja and Sethuraman 2008a). Although synthetic organic inhibitors have shown effective corrosion inhibition, their cost, toxicity, and non-biodegradability lead us to look for green options. In this review, we are discussing about the various plant extract and especially Azadirachta indica as green corrosion inhibitor for mild steel, Al, and tin (Tables 1, 2, and 3).

\section{Use of A. indica as a corrosion inhibitor against mild steel,} aluminum, and tin corrosion

A. indica (AZI, common name "Neem") is noteworthy for its biological and chemical uses (Fig. 1). It is known as "magical plant" for many diseases treatment (Kliski'c et al. 2000). It is very effective in the production of secondary metabolites (Kumar et al. 1996; Schaaf et al. 2000; Barton 1999). Neem is a member of the mahogany family, Meliaceae. Neem trees are attractive broad-leaved evergreens that can grow up to $30 \mathrm{~m}$ tall and $2.5 \mathrm{~m}$ in girth. Their scattering branches form rounded crowns as much as $20 \mathrm{~m}$ across. The fruit is a smooth, ellipsoidal drupe, up to almost $2 \mathrm{~cm}$ long (Jacobson 1986b).

The chemical compounds of neem belonged to a general class of natural products called "triterpenes" or "limonoids." These limonoids have an ability to block insects' growth who are responsible for harmful outcomes in agriculture and human health sector. New limonoids are still being discovered in neem, but azadirachtin, salannin, meliantriol, and nimbin are the best known and most significant ones (Qurasishi 2004). Nowadays, the use of neem as a corrosion inhibitorhas been widely investigated., so in Table 4, we summarize the corrosive properties of neem with respect to mild steel, aluminum, and tin metals.

Arab et al. (2008) found that AZI extract inhibits the corrosion of aluminum in $0.5 \mathrm{M} \mathrm{HCl}$. Sharma et al. (2013) investigated the inhibitory efficacy of ethanolic extract of $A$. indica fruit for acid corrosion of aluminum.

The corrosion inhibition and adsorption properties of neem (AZI) mature leaves extract as a green inhibitor of mild steel (MS) corrosion in nitric acid $\left(\mathrm{HNO}_{3}\right)$ solutions have been studied and investigated by Sharma et al. (2009a; Sharma et al. 2010c; Sharma et al. 2010d) using a gravimetric technique for experiments conducted at 30 and $60{ }^{\circ} \mathrm{C}$. According to Ayssar et al. (2010), the aqueous neem leaves extract was found to be an excellent potential corrosion inhibitor for carbon steel in $1.0 \mathrm{M} \mathrm{HCl}$. Obiukwu et al. (2013) mentioned that the $A$. indica had a better effect with an inhibitive efficiency of $85 \%$ for stainless steel. Investigation of Eddy and Mamza (2009) demonstrates that the rate of corrosion of mild steel in $\mathrm{H}_{2} \mathrm{SO}_{4}$ increases with the increase in the concentration of the acid and that ethanol extracts of the seeds and leaves of $A$. indica inhibit the corrosion of mild steel in $\mathrm{H}_{2} \mathrm{SO}_{4}$. According to Loto et al. (2011), the corrosion inhibition performance of neem leaf ( $A$. indica) extract on the corrosion of mild steel was achieved in the dilute hydrochloric acid at $0.25 \mathrm{~g} / \mathrm{l}$ extract concentration and also at $30{ }^{\circ} \mathrm{C}$. In a recent study by Desai (2015a), it has been discussed that in $\mathrm{HCl}, \mathrm{AZI}$ was an effective inhibitor against mild steel corrosion, the rate of corrosion increases with the increase in acid concentration and temperature. He also observed that a straight line in the plots of Langmuir adsorption isotherm suggests that the inhibitor's adsorption on steel followed Langmuir isotherm. Polarization study involved in this case indicates that the inhibitor functions as a mixed inhibitor (Desai 2015b). In an another study carried out by Ajanaku et al. (2015), authors highlighted that in the corrosion inhibition 
Table 1 Plants as corrosion inhibitors against mild steel corrosion

\begin{tabular}{|c|c|c|c|c|c|c|c|}
\hline Study Conducted & Plant product & Solution & $\begin{array}{l}\text { Effect of temperature } \\
\text { on percentage } \\
\text { inhibition efficiency }\end{array}$ & $\begin{array}{l}\text { Effect of concentration } \\
\text { on percentage } \\
\text { inhibition efficiency }\end{array}$ & Methods & $\begin{array}{l}\text { Adsorption type } \\
\text { and isotherm } \\
\text { used }\end{array}$ & Reference \\
\hline $\begin{array}{l}\text { Eichhornia crassipes is noted as one } \\
\text { of the most important and noxious } \\
\text { freshwater weed; the extracts of its } \\
\text { leaves and roots were reported as } \\
\text { good corrosion inhibitor for mild steel } \\
\text { corrosion in HCl solutions using } \\
\text { gasometric technique, and its modeled } \\
\text { structures provides additional insight } \\
\text { into the mechanism of inhibitory } \\
\text { action by DFT }\end{array}$ & E. crassipes (leaf and root) & $\mathrm{HCl}$ & $\begin{array}{l}\text { Decrease with rise } \\
\text { in temperature }\end{array}$ & Increase & $\begin{array}{l}\text { Gasometric } \\
\text { technique }\end{array}$ & $\begin{array}{l}\text { (Physically } \\
\text { adsorbed) }\end{array}$ & $\begin{array}{l}\text { Ulaeto et al. } \\
2012\end{array}$ \\
\hline $\begin{array}{l}\text { Nauclea latifolia commonly known as pin } \\
\text { cushion tree is a straggling shrub or } \\
\text { small spreading tree that belongs to the } \\
\text { family Rubiaceae. The effects of ethanol } \\
\text { (ENL), alkaloids (ANL), and non-alkaloids } \\
\text { (NNL) extracts from the root of } N \text {. latifolia } \\
\text { on the dissolution of carbon steel in } \mathrm{H}_{2} \mathrm{SO}_{4} \\
\text { solutions were shown their effective } \\
\text { inhibition by followed trend ANL }>\mathrm{ENL}> \\
\text { NNL. Gasometric method was use to } \\
\text { perform practical data and obtained } \\
\text { results show that percentage inhibition } \\
\text { efficiency increase with concentration but } \\
\text { decrease with rise in temperature }\end{array}$ & N. latifolia (root) & $\mathrm{H}_{2} \mathrm{SO}_{4}$ & $\begin{array}{l}\text { Decrease with rise } \\
\text { in temperature }\end{array}$ & Increase & $\begin{array}{l}\text { Gasometric } \\
\text { technique }\end{array}$ & Temkin & $\begin{array}{l}\text { Okafor et al. } \\
2013\end{array}$ \\
\hline $\begin{array}{l}\text { Banana peel extract (constituent of this } \\
\text { extract is bananadine ( } 3 Z, 7 Z, 10 Z)-1 \text {-oxa-6- } \\
\text { azacyclododeca-3,7,10-triene) was reported } \\
\text { as a good corrosion inhibitor with Zn in } \\
\text { distilled water for carbon steel corrosion } \\
\text { by the weight loss, thermometric, FTIR, } \\
\text { and AFM analysis. Obtained results show } \\
\text { that percentage inhibition efficiency first } \\
\text { decrease with the addition of Zn but after } \\
\text { increasing Zn concentration it increased }\end{array}$ & Banana peel extract $+\mathrm{Zn}$ & Distilled water & - & $\begin{array}{l}\text { First decrease with } \\
\text { Zn after increase with } \\
\text { increasing concentration } \\
\text { of Zn inhibition } \\
\text { efficiency increases }\end{array}$ & $\begin{array}{l}\text { Weight loss, } \\
\text { thermometric, } \\
\text { FTIR, and AFM } \\
\text { analysis }\end{array}$ & - & $\begin{array}{l}\text { Sangeetha } \\
\text { et al. } 2012\end{array}$ \\
\hline $\begin{array}{l}\text { By the use of quantum chemical calculations, } \\
\text { the active compound were reported as } \\
\text { follows: (Kalmegh) Andrographis paniculata- } \\
\text { andrographolide, (Meethi Neem) Murraya } \\
\text { koenigii- mahabinine and pyrayafoline, } \\
\text { (Bael) Aegle marmelos—-skimmianine, } \\
\text { (Kuchla) Strychnos nuxvomica-brucine, } \\
\text { (Shahjan) Moringa oleifera-arginine, (Orange) } \\
\text { Citrus aurantium - threonine, and (Arjun) } \\
\text { Terminalia arjuna-sitosterol, Due to these } \\
\text { active molecules, they show their inhibition } \\
\text { effect for corrosion }\end{array}$ & $\begin{array}{l}\text { The extracts of (Kalmegh) } \\
\text { Andrographis paniculata, (Meethi } \\
\text { Neem) Murraya koenigii, (Bael) } \\
\text { Aegle marmelos, (Kuchla) Strychnos } \\
\text { nuxvomica, (Shahjan) Moringa } \\
\text { oleifera, (Orange) Citrus aurantium, } \\
\text { and (Arjun) Terminalia arjuna }\end{array}$ & $\mathrm{HCl}$ & - & - & $\begin{array}{l}\text { DFT, molecule } \\
\text { analysis, and } \\
\text { quantum } \\
\text { calculations }\end{array}$ & - & $\begin{array}{l}\text { Singh et al. } \\
2013\end{array}$ \\
\hline
\end{tabular}
distilled water for carbon steel corrosion that percentage inhibition efficiency first

By the use of quantum chemical calculations,

(Kuchla) Strychnos nuxvomica-brucine,

Citrus aurantium - threonine, and (Arjun) 
Table 1 Plants as corrosion inhibitors against mild steel corrosion (Continued)

Aloe vera plant belongs to the family of

Liliacea. The constituents of gel are

polysaccharides, glycoproteins, vitamins,

mineral, and enzymes. Obtained results

show its synergistic type effect, and

percentage inhibition efficiency was

decrease with rise in temperature and

increase with increasing extract

concentration

C. sinensis leaf extract reported as a corrosion inhibitor in aqueous medium by the use of weight loss, UV, and FT-IT methods. Obtained results show that inhibition efficiency increase with increasing inhibitor concentration but decrease with rise in temperature

Hibiscus rosa-sinensis leaves extract reported as a good corrosion inhibitor for mild steel in $\mathrm{HCl}$ medium by the use of weight loss and EIS techniques.

Obtained results show that the

percentage inhibition efficiency was

increased with the increasing temperature

and concentration and show mixed-type

inhibitor effect, and adsorption process

was spontaneous and followed the

Langmuir, Flory-Huggins and Freundlich adsorption isotherms

Ilex paraguariensis extracts reported as a good corrosion inhibitor for carbon steel in $\mathrm{HCl}$ medium by the use of weight loss and EIS techniques. Its inhibition efficiency increased with the increase of concentration and time. Obtained results show that $I$. paraguariensis act as both type inhibitor and obeyed the Langmuir adsorption isotherm

Ruta graveolens extract reported as a good corrosion inhibitor for mild steel corrosion

in $\mathrm{HCl}$ medium by PDP and weight loss

method. Obtained results show that percentage

inhibition efficiency increase

with increasing concentration of inhibitor

but decrease with rise in temperature and obeyed the Langmuir adsorption isotherm

Musa sapientum which is commonly called banana is a herbaceous plant belonging to the family of Musaceae. It is reported as a good corrosion inhibitor
Aloe vera

$\mathrm{HNO}_{3}$

Decrease with rise

Increase

in temperature

Gravimetric

technique

Chemisorption

Gupta and

Jain 2014

C. sinensis leaf extract

Aqueose

Decrease with rise

Decrease

in temperature

Weight loss method, Physical

pH, UV-vis, and FT-IR adsorption

Yamuna and

Athony 2014

H. rosa-sinensis (Jasud)

Increase

Increase

(weight loss)

and electrochemic

Langmuir,

Flory-Huggins

techniques

and Freundlic
1. paraguariensis

$\mathrm{HCl}$

$\mathrm{HCl}$

R. graveolens extract

M. sapientum peels extract +

concentrated

(vi) acid

\section{Decrease with rise Increase in temperature}

Potentiodynamic polarization and

weight loss

Langmuir

adsorption

isotherm

Majeed et al.

techniques

Langmuir

adsorption

Souza et al.

electrochemical

isotherm

2015

Weight loss, E.

chemical

Physical

adsorption

Salami et al.

measurements 
Table 1 Plants as corrosion inhibitors against mild steel corrosion (Continued)

for mild steel in $\mathrm{H}_{2} \mathrm{SO}_{4}$ medium with

tetraoxosulphate (vi) acid by the use of

E. chemical measurements. Obtained

results show that corrosion rate decrease

with increasing concentration rate of

inhibitor but increase with rising temperature.

Simply followed the physical adsorbtion

Extract of fenugreek leaves reported as a

good inhibitor for mild steel in $\mathrm{HCl}$ and

$\mathrm{H}_{2} \mathrm{SO}_{4}$ solution but more efficient in $\mathrm{HCl}$

solution. Inhibition efficiency was decrease

with rise in temperature but increase with

increasing inhibitor concentration in $\mathrm{HCl}$

while both temperature and concentration

increased the inhibition efficiency for mild

steel in $\mathrm{H}_{2} \mathrm{SO}_{4}$ solution. Langmuir adsorption

isotherm followed in $\mathrm{HCl}$ medium and

Temkin followed in $\mathrm{H}_{2} \mathrm{SO}_{4}$ medium

Cotula cinerea, Retama retam, Artemisia herba reported as good corrosion inhibitors for mild

Extract of fenugreek leaves

$\mathrm{HCl}$ and
$\mathrm{H}_{2} \mathrm{SO}_{4}$

Cotula cinerea, Retama retam Artemisia herba

steel in $\mathrm{H}_{2} \mathrm{SO}_{4}$ medium by weight loss and

\section{ElS methods}

Eclipta alba reported as an effective corrosion E. alba

inhibitor for mild steel in $\mathrm{H}_{2} \mathrm{SO}_{4}$ medium by

the use of weight loss and potentiodynamic

polarization methods. Obtained results

show that inhibitor behave as mixed-type

inhibitor; inhibition efficiency increase with

concentration value but decrease with rise

in temperature. Obeyed the Langmuir

adsorption isotherm

Terminalia catappa reported as a corrosion

inhibitor in $\mathrm{HCl}$ medium by the use of weight

loss and PDP methods. Obtained results show

that inhibition efficiency increased with

increasing concentration of inhibitor but

decrease with rise in temperature and

described as mixed-type inhibitor

Theobroma cacao peel polar extract reported as a corrosion inhibitor for mild steel in $\mathrm{HC}$

medium by the use of weight loss method

potentiodynamic polarization, and EIS

techniques. Obtained results show that

inhibition efficiency increased with the

inhibitor concentration level but decreased

with the rise in temperature and obeyed the

Langmuir adsorption isotherm

$\mathrm{H}_{2} \mathrm{SO}_{4}$

$\mathrm{H}_{2} \mathrm{SO}_{4}$

T. cacao peel pola extract (TCPE)

$\mathrm{HCl}$

\begin{tabular}{|c|c|c|c|}
\hline $\begin{array}{l}\text { Decrease in } \mathrm{HCl} \\
\text { solution but } \\
\text { increase In } \mathrm{H}_{2} \mathrm{SO}_{4} \\
\text { solution }\end{array}$ & $\begin{array}{l}\text { Increase in both } \\
\text { solutions }\end{array}$ & $\begin{array}{l}\text { Gravimetric } \\
\text { technique }\end{array}$ & $\begin{array}{l}\text { Langmuir in } \\
\mathrm{HCl} \text { solution, } \\
\text { Temkin in }\end{array}$ \\
\hline
\end{tabular}

solution

Decrease with rise in temperature

Increase

Weight Loss and

E chemical

measurements

$-$

Sethuraman

Weight loss,

potentiodynamic

Langmuir adsorption

$\mathrm{H}_{2} \mathrm{SO}_{4}$ solution

impedance methods

Weight loss,

polarization, FTR,

Mixed-type

inhibition

Vasudha and

and scanning

electron microscope

studies

Decrease

Increase

Weight loss method,

Langmui potentiodynamic adsorptio polarization, and EIS isotherm techniques 
Table 1 Plants as corrosion inhibitors against mild steel corrosion (Continued)

It's reported that the mature leaves of

Combretum bracteosum extracts inhibited the

Combretum bracteosum extracts inhibited the

corrosion of mild steel in $\mathrm{H}_{2} \mathrm{SO}_{4}$ medium
the use of gravimetric and hydrogen

evolution methods. Obtained results show

that the inhibition efficiency increases with

the inhibitor concentration and decreases

with temperature. Obtained result obeyed

the Frumkin adsorption isotherm

Cyamopsis tetragonoloba reported as an

effective corrosion inhibitor for mild steel in

$\mathrm{HCl}$ medium by use of weight loss, PDP, and

EIS techniques. Obtained results show that

inhibitor concentration but decrease with rise

in temperature. Obeyed the Temkin and

Langmuir adsorption isotherms 
Table 2 Plants as corrosion inhibitors against aluminum corrosion

\begin{tabular}{|c|c|c|c|c|c|c|c|}
\hline Study Conducted & Plant product & Solution & $\begin{array}{l}\text { Effect of temperature } \\
\text { on percentage } \\
\text { inhibition efficiency }\end{array}$ & $\begin{array}{l}\text { Effect of concentration } \\
\text { on percentage } \\
\text { inhibition efficiency }\end{array}$ & Methods & Adsorption & Reference \\
\hline $\begin{array}{l}\text { Phoenix dactylifera reported as a good corrosion inhibitor for } \\
\text { Al in NaOH solution by weight loss and PDP method. } \\
\text { Obtained results show that inhibition efficiency increase } \\
\text { with increasing temperature and concentration, followed } \\
\text { the Temkin adsorption isotherm also }\end{array}$ & P. dactylifera, & $\mathrm{NaOH}$ & Increase & Increase & $\begin{array}{l}\text { Weight loss, } \\
\text { potentiodynamic } \\
\text { polarization }\end{array}$ & $\begin{array}{l}\text { Temkin adsorption } \\
\text { isotherm }\end{array}$ & Rehan 2003 \\
\hline $\begin{array}{l}\text { The extracts of Damsissa, Corchours oitorius reported as a good } \\
\text { inhibitor for the corrosion of aluminum in aqueous sodium } \\
\text { carbonate by the use of gasometry, potentiodynamic polarization, } \\
\text { and electrochemical impedance spectroscopy (EIS) }\end{array}$ & $\begin{array}{l}\text { Extracts of } \\
\text { Damsissa, } \\
\text { Corchours } \\
\text { oitorius }\end{array}$ & $\begin{array}{l}\text { Sodium } \\
\text { carbonate }\end{array}$ & Decrease & Increase & $\begin{array}{l}\text { Gasometry, } \\
\text { potentiodynamic } \\
\text { polarization }\end{array}$ & $\begin{array}{l}\text { Langmuir and } \\
\text { Flory-Huggins }\end{array}$ & $\begin{array}{l}\text { Abd-El-Nabey } \\
\text { et al. } 2012\end{array}$ \\
\hline $\begin{array}{l}\text { Rosmarinus officinalis reported as a good corrosion inhibitor for } \\
\text { aluminum in } \mathrm{NaCl} \text { solution by the use of PDP method. Obtained } \\
\text { result obeyed the Freundlich isotherm }\end{array}$ & R. officinalis & $\begin{array}{l}\text { Chloride } \\
\text { solution }\end{array}$ & $\begin{array}{l}\text { Decrease with } \\
\text { rise in temperature }\end{array}$ & Increase & $\begin{array}{l}\text { Potentiodynamic } \\
\text { polarization }\end{array}$ & $\begin{array}{l}\text { Freundlich } \\
\text { isotherm }\end{array}$ & $\begin{array}{l}\text { Kliski'c et al. } \\
2000\end{array}$ \\
\hline $\begin{array}{l}\text { The dissolution of } \mathrm{Al} \text { and } \mathrm{Zn} \text { in } \mathrm{HCl} \text { and } \mathrm{NaOH} \text { medium were } \\
\text { inhibited by } \mathrm{H} \text {. subdariffa (Karkade) extract. Obtained results } \\
\text { show that corrosion rate increase with increasing temperature } \\
\text { but decrease with increasing concentration. Physical adsorption } \\
\text { phenomena were observed }\end{array}$ & $\begin{array}{l}\text { H. subhdariffa } \\
\text { extract }\end{array}$ & $\begin{array}{l}\mathrm{HCl} \text { and } \\
\mathrm{NaOH}\end{array}$ & $\begin{array}{l}\text { Decrease with rise } \\
\text { in temperature }\end{array}$ & Increase & $\begin{array}{l}\text { Weight loss and } \\
\text { the galvanostatic } \\
\text { polarization }\end{array}$ & $\begin{array}{l}\text { Physical } \\
\text { adsorption }\end{array}$ & $\begin{array}{l}\text { El-hosary et al. } \\
1972\end{array}$ \\
\hline $\begin{array}{l}\text { Vernonia amygdalina reported as a fine corrosion inhibitor for } \\
\text { aluminum in } \mathrm{HCl} \text { and } \mathrm{HNO}_{3} \text { medium by the use of weight loss } \\
\text { method. But its inhibition performance was much better in } \mathrm{HNO}_{3} \\
\text { solution as compare to } \mathrm{HCl} \text { medium }\end{array}$ & V. amygdalina & $\begin{array}{l}\mathrm{HNO}_{3} \text { and } \\
\mathrm{HCl}\end{array}$ & - & Increase & $\begin{array}{l}\text { Weight loss } \\
\text { method }\end{array}$ & - & $\begin{array}{l}\text { Avwiri and Igho } \\
2003\end{array}$ \\
\hline $\begin{array}{l}\text { Saccharides (fructose and mannose) with the addition of } \\
\text { ascorbic acid addition, reported as a good corrosion inhibitor } \\
\text { for Al by the method of hydrogen evolution in alkaline medium }\end{array}$ & $\begin{array}{l}\text { Saccharides } \\
\text { (fructose and } \\
\text { mannose) }\end{array}$ & $\begin{array}{l}\text { Alkaline } \\
\text { medium }\end{array}$ & - & - & $\begin{array}{l}\text { Evolution of } \\
\text { hydrogen }\end{array}$ & - & Muller 2002 \\
\hline $\begin{array}{l}\text { The inhibitive effect of leaf extracts of Euphorbia hirta and Dialum } \\
\text { guineense on aluminum alloy (AA8011) was reported in } \mathrm{HCl} \\
\text { solution by the use of gravimetric technique. The results indicate } \\
\text { that both extracts worked as good inhibitors and inhibition } \\
\text { efficiency improved with concentration }\end{array}$ & $\begin{array}{l}\text { Leaf extracts } \\
\text { of E. hirta and } \\
\text { D. guineense }\end{array}$ & $\mathrm{HCl}$ & Decrease & Increase & $\begin{array}{l}\text { Gravimetric } \\
\text { technique }\end{array}$ & $\begin{array}{l}\text { Langmuir } \\
\text { adsorption } \\
\text { isotherm }\end{array}$ & $\begin{array}{l}\text { Anozie et al. } \\
2011\end{array}$ \\
\hline $\begin{array}{l}\text { The inhibition effect of Newbouldia laevis leaves extract reported } \\
\text { as a good inhibitor on the corrosion of aluminum } \mathrm{HCl} \text { and } \mathrm{H}_{2} \mathrm{SO}_{4} \\
\text { solutions by the use of gravimetric technique. Obtained results } \\
\text { show that } \mathrm{N} \text {. laevis inhibitor effect was more efficient in } \mathrm{HCl} \\
\text { than } \mathrm{H}_{2} \mathrm{SO}_{4} \text {. }\end{array}$ & $\begin{array}{l}\text { N. laevis leaves } \\
\text { extract }\end{array}$ & $\begin{array}{l}\mathrm{HCl} \text { and } \\
\mathrm{H}_{2} \mathrm{SO}_{4}\end{array}$ & Decrease & Increase & $\begin{array}{l}\text { Gravimetric } \\
\text { technique }\end{array}$ & Langmuir & $\begin{array}{l}\text { Nnanna et al. } \\
2012\end{array}$ \\
\hline $\begin{array}{l}\text { Coconut coir dust extract reported as a good inhibitor for aluminum } \\
\text { corrosion in } 1 \mathrm{M} \mathrm{HCl} \text { medium by the use of weight loss and hydrogen } \\
\text { evolution method. It was exhibited that percentage IE efficiency } \\
\text { increased with increasing temperature and concentration. Obtained } \\
\text { results show the Langmuir adsorption performance }\end{array}$ & $\begin{array}{l}\text { Coconut coir } \\
\text { dust extract }\end{array}$ & $1 \mathrm{M} \mathrm{HCl}$ & Increase & Increase & $\begin{array}{l}\text { Weight loss } \\
\text { and hydrogen } \\
\text { evolution }\end{array}$ & Langmuir & $\begin{array}{l}\text { Umoren et al. } \\
2012\end{array}$ \\
\hline
\end{tabular}

Vernonia amygdalina reported as a fine corrosion inhibitor for solution as compare to HCl medium

exfect of Newbouldia laevis leaves extract rep

results show the Langmuir adsorption performance




Table 3 Plants as corrosion inhibitors against tin corrosion

\begin{tabular}{|c|c|c|c|c|c|c|c|}
\hline Study Conducted & Material & Solution & $\begin{array}{l}\text { Effect of temperature } \\
\text { on percentage inhibition } \\
\text { efficiency }\end{array}$ & $\begin{array}{l}\text { Effect of concentration } \\
\text { on percentage inhibition } \\
\text { efficiency }\end{array}$ & Methods & Adsorption & Reference \\
\hline $\begin{array}{l}\text { It is reported that lysine, arginine, methionine, } \\
\text { cysteine were good corrosion inhibitors in citric } \\
\text { acid solution by the potentiodynamic methods. } \\
\text { Nitron-containing acids show } 70 \% \text { inhibition as } \\
\text { compared with sulfur-containing acids. All four } \\
\text { acids act as a mixed-type inhibitor and show } \\
\text { their inhibition effect on tin corrosion and } \\
\text { obeyed Temkin adsorption isotherm. }\end{array}$ & $\begin{array}{l}\text { Amino acids (lysine, arginine, } \\
\text { methionine, and cysteine) }\end{array}$ & Citric acid & $\begin{array}{l}\text { Decrease with rise in } \\
\text { temperature }\end{array}$ & $\begin{array}{l}\text { Increase but decrease after } \\
\text { optimum concentration }\end{array}$ & $\begin{array}{l}\text { Potentiodynamic } \\
\text { polarization (PDP) }\end{array}$ & $\begin{array}{l}\text { Temkin } \\
\text { adsorption }\end{array}$ & $\begin{array}{l}\text { Quraishi et al. } \\
2004\end{array}$ \\
\hline $\begin{array}{l}\text { Alanine, glycine, glutamic acid, and histidine } \\
\text { were used as environmentally safe inhibitors } \\
\text { for the tin dissolution process }\end{array}$ & Amino acids (glycine) & Tartaric acid & Decrease & Increase & $\begin{array}{l}\text { Weight loss, } \\
\text { SEM, and EIS }\end{array}$ & $\begin{array}{l}\text { Freundlich } \\
\text { isotherm }\end{array}$ & $\begin{array}{l}\text { El-Sherif Rabab } \\
\text { and Badawy } \\
\text { Waheed } 2011\end{array}$ \\
\hline $\begin{array}{l}\text { Different varieties of holy basil, viz., Ocimum } \\
\text { basilicum (EB), Ocimum cannum (EC), and } \\
\text { Ocimum sanctum (ES) reported as corrosion } \\
\text { inhibitors for tin in } \mathrm{HNO}_{3} \text { solution by the } \\
\text { use of weight loss techniques. Obtained } \\
\text { results show that inhibition efficiency } \\
\text { increase with inhibitor concentration. } \\
\text { Followed Langmuir adsorption isotherm }\end{array}$ & $\begin{array}{l}\text { The leaves and stem extract } \\
\text { of different varieties of holy } \\
\text { basil, viz., O. basilicum (EB), } \\
\text { O. cannum (EC), and O. } \\
\text { sanctum (ES) }\end{array}$ & $\mathrm{HNO}_{3}$ & - & Increase & $\begin{array}{l}\text { Weight loss } \\
\text { technique }\end{array}$ & Langmuir & $\begin{array}{l}\text { Kumpawat } \\
\text { et al. } 2012\end{array}$ \\
\hline
\end{tabular}




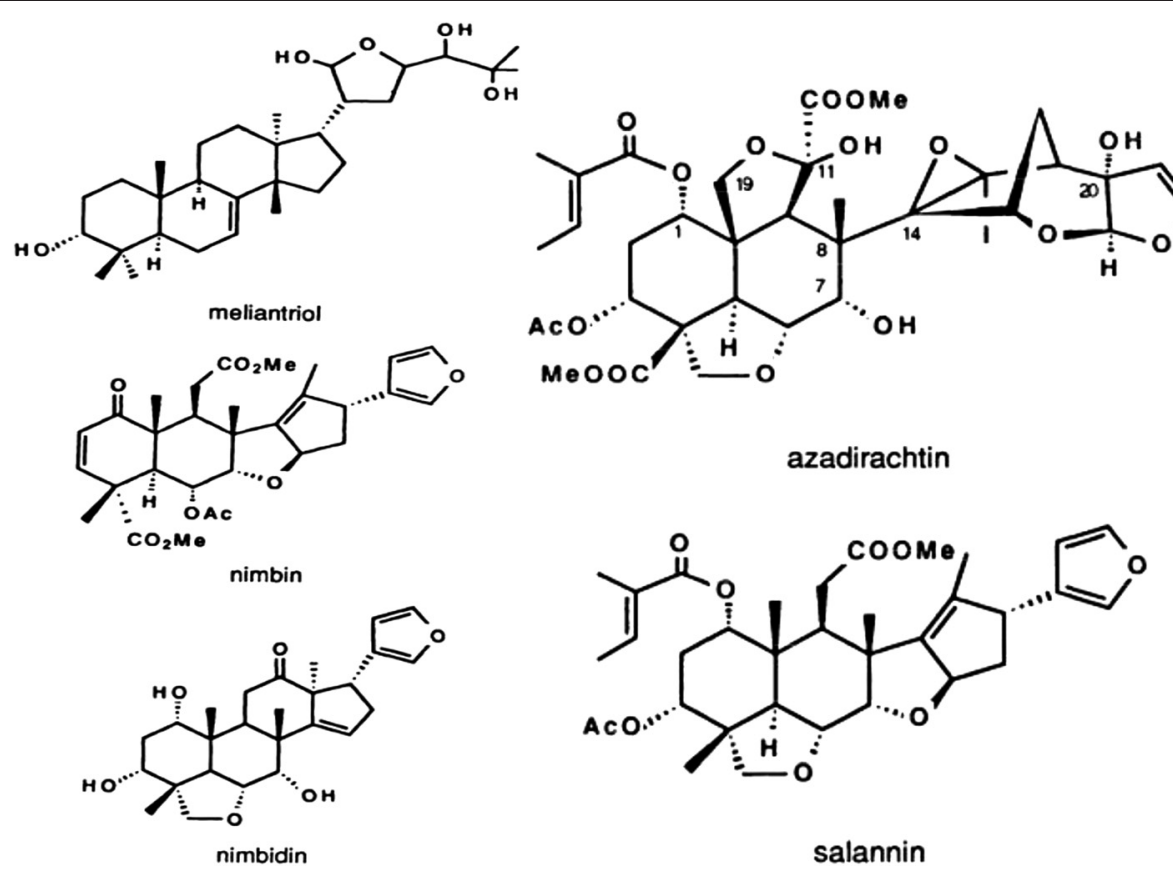

Fig. 1 Main chemical compounds present in Azadirachta indica

study of AZI against aluminum metal in $1.85 \mathrm{M}$ hydrochloric acid, the rate of the reaction has been studied by monitoring and measuring the volume of hydrogen gas evolved and the results were supported by various adsorption theories and the surface morphology studies using scanning electron microscopy (SEM). Authors suggested that the plant extract retards the acid-induced corrosion of aluminum and the volume of hydrogen gas evolved reduced with increasing extract concentration. Also, the Langmuir isotherm as the best model for the adsorption of $A$. indica indicates the suggested mechanism of adsorption-chemisorption (Ajanaku et al. 2015). A research conducted by Jain et al. (a research group at Tata Steel, Jamshedpur) published in Tata Search (2014) also highlighted the inhibition effect of AZI against mild steel in acid media $\left(\mathrm{HCl}\right.$ and $\left.\mathrm{HNO}_{3}\right)$, and the results of weight loss studies correlated well with polarization studies (Jain et al. 2014).

In a very interesting study by Bhola et al. (2014) published in Engineering Failure Analysis, authors investigated the inhibition effect of AZI extract on microbiologically influenced corrosion of API 5L X80 line pipe steel by a sulfate reducing bacterial (SRB) consortium. On the basis of the field emission scanning electron microscopy (FE-SEM) and energy dispersive spectroscopy (EDS) studies, electrochemical impedance spectroscopy (EIS), linear polarization resistance (LPR), and open circuit potential (OCP) were used to investigate the in situ corrosion behavior, and they concluded that neem extract has the capability to reduce the biocorrosion rate by approximately $50 \%$ (Bhola et al. 2014), which is fairly high and very encouraging, clearly underlining the importance of AZI extract as a corrosion inhibitor.

\section{Corrosion inhibition by AZI and computational modeling}

Computational methods are more and more appropriate in the study of corrosion inhibition capacity because they have the potential to support in the design of new compounds with good corrosion inhibition properties. These studies are assisting in reducing the experimental costs for testing many compounds with the objective of synthesizing the ones that have high promise for corrosion inhibition. Density functional theory (DFT) and molecular dynamics (MD) approaches are increasingly used for predicting the inhibition potential of compound for corrosion on geometrical, electronic, and binding property bases on metal surface (Kabanda et al. 2012b; Kabanda and Ebenso 2012; Ebenso et al. 2012b). Recently, more corrosion publications contained substantial quantum chemical calculations and molecular dynamics simulations (Obot et al. 2013; Kabanda et al. 2013; Obot and Gasem 2014). Such calculations are usually used to explore the relationship between the inhibitor molecular properties and their corrosion inhibition efficiencies. The use of quantum chemical methods in corrosion inhibitor studies of large number of small organic compounds has been highlighted by Gece (2008) and Obot (2014) in their detailed review. Attempt has 
Table 4 Azadirachta indica as corrosion inhibitor

\begin{tabular}{|c|c|c|c|c|c|c|c|c|}
\hline Concise manner & Metal & Plant product & Solution & $\begin{array}{l}\text { Effect of temperature } \\
\text { on percentage } \\
\text { inhibition efficiency }\end{array}$ & $\begin{array}{l}\text { Effect of concentration } \\
\text { on percentage } \\
\text { inhibition efficiency }\end{array}$ & Methods & $\begin{array}{l}\text { Adsorption type } \\
\text { and isotherm } \\
\text { used }\end{array}$ & Reference \\
\hline $\begin{array}{l}\text { Mature leaves extract of neem reported as } \\
\text { a green corrosion inhibitor for } \mathrm{Zn} \text { in } \mathrm{HCl} \\
\text { medium by the use of gravimetric and } \\
\text { thermometric methods }\end{array}$ & $\mathrm{Zn}$ & $\begin{array}{l}\text { Mature } \\
\text { leaves } \\
\text { of neem }\end{array}$ & $\mathrm{HCl}$ & Decrease & Increase & $\begin{array}{l}\text { Gravimetric and } \\
\text { thermometric }\end{array}$ & $\begin{array}{l}\text { Physical } \\
\text { adsorption }\end{array}$ & $\begin{array}{l}\text { Sharma et al. } \\
2010 c\end{array}$ \\
\hline $\begin{array}{l}\text { Dry seed extract of AZI reported as a good } \\
\text { inhibitor for mild copper corrosion in } \mathrm{HNO}_{3} \\
\text { medium by weight loss and phytochemical } \\
\text { analysis. Obtained results show that percentage } \\
\text { inhibition efficiency increase with increasing } \\
\text { concentration and show mixed } \\
\text { type inhibition }\end{array}$ & Mild copper & $\begin{array}{l}\text { Dry seeds } \\
\text { extracts } \\
\text { of AZI }\end{array}$ & $\mathrm{HNO}_{3}$ & Decrease & Increase & $\begin{array}{l}\text { Weight loss and } \\
\text { phytochemical } \\
\text { analysis }\end{array}$ & $\begin{array}{l}\text { Mixed-type } \\
\text { adsorption. }\end{array}$ & $\begin{array}{l}\text { Sangeetha } \\
\text { and Fredimoses } \\
2011\end{array}$ \\
\hline $\begin{array}{l}\text { There were selected plants [Occimum viridis } \\
\text { (OV), Telferia occidentalis (TO), Azadirachta } \\
\text { indica (AZI), Hibiscus sabdariffa (HS), Garcinia } \\
\text { kola (GK)] which extracts reported as good } \\
\text { corrosion inhibitors for mild steel corrosion } \\
\text { in } \mathrm{HCl} \text { and } \mathrm{H}_{2} \mathrm{SO}_{4} \text { by gasometric method. } \\
\text { Obtained results indicate that all the extracts } \\
\text { inhibited the corrosion process in both acid } \\
\text { media and the presence of halide additive } \\
\text { increase inhibition efficiency due to } \\
\text { synergistic effect }\end{array}$ & Mild steel & $\begin{array}{l}\mathrm{AZZ}+\text { halide } \\
\text { additive }\end{array}$ & $\mathrm{HCl}$ and $\mathrm{H}_{2} \mathrm{SO}_{4}$ & No dependence & Increase & $\begin{array}{l}\text { Kinetics activation } \\
\text { parameters and } \\
\text { gasometric } \\
\text { technique }\end{array}$ & - & Oguzie 2008 \\
\hline $\begin{array}{l}\text { It is reported that AZI with iodide additive } \\
\text { shows good inhibition for Al corrosion in } \\
\mathrm{HCl} \text { medium by PDP method. Due to } \\
\text { synergistic effect, the adsorption was } \\
\text { spontaneous and followed the Freundlich } \\
\text { adsorption isotherm }\end{array}$ & $\mathrm{Al}$ & $\begin{array}{l}\text { AZI and iodide } \\
\text { ions as }\end{array}$ & $\mathrm{HCl}$ & Decrease & Increase & PDP techniques & $\begin{array}{l}\text { Freundlich } \\
\text { adsorption } \\
\text { isotherm }\end{array}$ & Arab et al. 2008 \\
\hline $\begin{array}{l}\text { Azadirachta indica extract reported as an } \\
\text { effective inhibitor for steel corrosion in the } \\
\text { acid media by the gas volumetric techniques } \\
\text { and obtained results show that consistence } \\
\text { of Langmuir adsorption isotherm }\end{array}$ & Mild steel & AZl extracts & $\begin{array}{l}\text { Different } \\
\text { concentrations of } \\
\mathrm{HCl}\end{array}$ & Decrease & Increase & $\begin{array}{l}\text { Gas volumetric } \\
\text { technique }\end{array}$ & $\begin{array}{l}\text { Langmuir } \\
\text { isotherm } \\
\text { adsorption } \\
\text { (mixed } \\
\text { inhibitor) }\end{array}$ & Oguzie 2006 \\
\hline $\begin{array}{l}\text { AZI reported as Al corrosion inhibitor in } \mathrm{HCl} \\
\text { medium by the use of weight loss and } \\
\text { thermometric methods. Obtained results } \\
\text { show that adsorption was exothermic, } \\
\text { spontaneous, and obeyed the Freundlich, } \\
\text { Temkin, and Flory-Huggins }\end{array}$ & $\mathrm{Al}$ & AZI & $\mathrm{HCl}$ & $\begin{array}{l}\text { Decrease with rise } \\
\text { in temperature }\end{array}$ & Increase & $\begin{array}{l}\text { Weight loss and } \\
\text { thermometric }\end{array}$ & $\begin{array}{l}\text { Freundlich, } \\
\text { Temkin, and } \\
\text { Flory-Huggins }\end{array}$ & $\begin{array}{l}\text { Ebenso et al. } \\
2004\end{array}$ \\
\hline $\begin{array}{l}\text { AZI leaves reported as a corrosion inhibitor } \\
\text { for mild steel in } \mathrm{H}_{2} \mathrm{SO}_{4} \text { medium by the use } \\
\text { of weight loss technique }\end{array}$ & Mild steel & AZI leaves & $\mathrm{H}_{2} \mathrm{SO}_{4}$ & - & - & $\begin{array}{l}\text { Weight loss } \\
\text { technique }\end{array}$ & $\begin{array}{l}\text { Physical } \\
\text { adsorption }\end{array}$ & $\begin{array}{l}\text { Ebenso et al. } \\
1998\end{array}$ \\
\hline $\begin{array}{l}\text { Ethanolic extract of AZI fruit reported as a } \\
\text { good inhibitor for aluminum corrosion in } \\
\mathrm{HCl} \text { medium by the use of weight loss }\end{array}$ & $\mathrm{Al}$ & $\begin{array}{l}\text { Ethanolic } \\
\text { extract of } \\
\text { AZI fruit }\end{array}$ & $\mathrm{HCl}$ & $\begin{array}{l}\text { Decrease with rise } \\
\text { in temperature }\end{array}$ & Increase & $\begin{array}{l}\text { Weight loss } \\
\text { thermometric }\end{array}$ & $\begin{array}{l}\text { Langmuir } \\
\text { adsorption } \\
\text { isotherm }\end{array}$ & $\begin{array}{l}\text { Sharma et al. } \\
2013\end{array}$ \\
\hline
\end{tabular}


Table 4 Azadirachta indica as corrosion inhibitor (Continued)

thermometric method. Obtained results show

the presence of physical adsorption process

like percentage inhibition efficiency increase

with increasing concentration but decrease

with rise in temperature and followed Langmuir adsorption isotherm

AZI mature leaf extract reported as good

inhibitor for mild steel corrosion in $\mathrm{HNO}_{3}$

medium by the use of gravimetric method.

Obtained results show that percentage

inhibition efficiency increased with increasing

concentration but get down with the rise in

temperature. Adsorption process was

exothermic and consistent and best fitted

into Frumkin adsorption isotherm

UAE neem extract reported as a good in

hibitor for carbon steel corrosion in $\mathrm{HCl}$

medium by the use of weight loss method

and obtained results show that percentage

inhibition efficiency increase with increasing

inhibitor concentration but decrease with

rise in temperature and data was fit into

Temkin adsorption isotherm

The inhibition effect of AZl extract reported as good inhibitor on stainless steel corrosion in $\mathrm{HCl}$ and $\mathrm{H}_{2} \mathrm{SO}_{4}$ medium by the weight loss method. Obtained results show that extract of AZI was better inhibitor as compare with other extract

It is reported that ethanol extract of leaves and seeds of $A$. indica shows its effective inhibition effect on mild steel corrosion in

$\mathrm{H}_{2} \mathrm{SO}_{4}$ medium by the use of gasometric, gravimetric, and IR methods. Corrosion

inhibition efficiency of the leaves is better

than that of the seeds.According to findings, the reaction followed the physical adsorption and fit in Flory-Huggins adsorption isotherm

It is reported that the inhibition effect of AZI extract on mild steel corrosion in acidic medium was good but it's more clearly visible in $\mathrm{HCl}$ medium as comparison with $\mathrm{H}_{2} \mathrm{SO}_{4}$ solution. In $\mathrm{HCl}$ medium the percentage inhibition

efficiency was increase with increasing

concentration of inhibitor but it gets down on

high temperature Obtained results show the

physical adsorption performance

Mild steel

AZI mature leaf extract

$\mathrm{HNO}_{3}$

Decrease with rise in temperature

Increase

techniques

Frumkin

adsorption

isotherm

2010d

Carbon steel UAE neem

extract

Decrease with rise

Increase

in temperature

Weight loss

method

Temkin

adsorption

isotherm

Stainless steel Plant extract

$\mathrm{HCl}+\mathrm{H}_{2} \mathrm{SO}_{4}+$ Decrease at high etraoxosulphate temperature

(IV) acid +

trioxnitrate $(V)$

acid solution

$\begin{array}{ll}\text { Mild steel } & \text { Ethanol } \\ & \text { extracts of } \\ \text { seeds and } \\ \text { leaves }\end{array}$

Decrease

Mild steel Extra in temperature
Extract of $\mathrm{AZI} \quad \mathrm{HCL}$ and $\mathrm{H}_{2} \mathrm{SO}_{4}$ Decrease with rise Increase
Weight loss and Physical PDP method adsorption
Weight loss

method

Physical

adsorption

biukwu et al. 2013

Gravimetric,

gasometric, and
IR methods

Flory-Huggin adsorption

Eddy and

sotherm 
Table 4 Azadirachta indica as corrosion inhibitor (Continued)

\begin{tabular}{|c|c|c|c|c|c|c|c|}
\hline $\begin{array}{l}\text { Neem leaf extract reported as a good corrosion } \\
\text { inhibitor for mild steel in chloride medium by } \\
\text { the gravimetric method. It showed a comparison } \\
\text { with or without neem leaf extract in salty water } \\
\text { medium with heat treatment. IE increased with the } \\
\text { increasing concentration of inhibitor in chloride- } \\
\text { and heat-treated chloride medium but its } \\
\text { decreased without inhibitor in chloride- and } \\
\text { heat-treated chloride medium }\end{array}$ & $\begin{array}{l}\text { Extract of } \\
\text { AZI leaf }\end{array}$ & $\begin{array}{l}\text { Chloride (salty } \\
\text { water medium) }\end{array}$ & $\begin{array}{l}\text { Increase in neem + } \\
\text { chloride medium } \\
\text { but decrease in } \\
\text { only-chloride } \\
\text { medium }\end{array}$ & $\begin{array}{l}\text { Increase in neem + } \\
\text { chloride medium } \\
\text { but decrease in } \\
\text { only-chloride } \\
\text { medium }\end{array}$ & & & $\begin{array}{l}\text { Tuaweri et al. } \\
2015\end{array}$ \\
\hline $\begin{array}{l}\text { Neem bark reported as efficient corrosion inhibitor Mild steel } \\
\text { for mild steel in HCl medium by the use of PDP } \\
\text { method. Percentage IE efficiency increased with } \\
\text { increased concentration but decreased with the } \\
\text { rise in temperature and reported data fit into } \\
\text { Langmuir adsorption isotherm }\end{array}$ & Neem ark & $\mathrm{HCl}$ & $\begin{array}{l}\text { Decrease with rise } \\
\text { in temperature }\end{array}$ & Increase & $\begin{array}{l}\text { Potentiodynamic } \\
\text { polarization }\end{array}$ & $\begin{array}{l}\text { Langmuir } \\
\text { (mixed-type } \\
\text { inhibition ) }\end{array}$ & Desai 2015b \\
\hline
\end{tabular}


Table 5 Important molecular descriptors derived from DFT and molecular dynamics simulations (Obot et al. 2013)

\begin{tabular}{|c|c|}
\hline Descriptors & Explanation \\
\hline \multicolumn{2}{|l|}{$\begin{array}{l}\text { Global quantum chemical } \\
\text { descriptors }\end{array}$} \\
\hline$E_{\text {HOMO }}$ & Energy of the highest occupied molecular orbital \\
\hline$E_{\text {LUMO }}$ & Energy of the lowest unoccupied molecular orbital \\
\hline $\mathrm{IP}\left(\approx-E_{\mathrm{HOMO}}\right)$ & Ionization potential: removing an electron from a molecular system $X\left(X \rightarrow X^{+}+e^{-}\right)$ \\
\hline$E A\left(\approx-E_{L U M O}\right)$ & Electron affinity: attaching an additional electron to a molecular system $X\left(X+\mathrm{e}^{-} \rightarrow \mathrm{X}^{-}\right)$ \\
\hline$\mu=\left(\frac{\delta E}{\delta N}\right)_{v}$ & Chemical potential, defined as the change in electronic energy $E$ upon change in total number of electrons $N$ \\
\hline$X=-\mu \approx-1 / 2\left(E_{\mathrm{HOMO}}+E_{\mathrm{LUMO}}\right)$ & Absolute electronegativity \\
\hline$\eta=-\left(\frac{\delta \mu}{\delta N}\right)_{V} \approx-\left(E_{\mathrm{HOMO}}-E_{\mathrm{LUMO}}\right)$ & Molecular hardness, defined as the change in chemical potential $\mu$ upon change in total number of electrons $N$ \\
\hline$S=\frac{1}{2 \eta}$ & Molecular softness \\
\hline$A$ & $\begin{array}{l}\text { Molecular polarizability; note that molecules arrange themselves towards a state of minimum polarizability and } \\
\text { maximum hardness }\end{array}$ \\
\hline$\omega=\frac{\mu^{2}}{2 \eta}=\frac{\chi^{2}}{2 \eta}$ & Electrophilicity index \\
\hline \multicolumn{2}{|l|}{ Charge distribution } \\
\hline$Q A(r)$ & Net atomic charges (at atom r) \\
\hline $\begin{array}{l}E_{\text {interaction }}=E_{\text {total }}-\left(E_{\text {surface }}+\right. \\
\left.E_{\text {inhibitor }}\right)\end{array}$ & $\begin{array}{l}\text { Where } E_{\text {total }} \text { is the total energy of the metal surface and inhibitor, } E_{\text {surface }} \text { is the metal surface energy and } E_{\text {inhibitor }} \text { is } \\
\text { the energy of inhibitor molecule from plant extract }\end{array}$ \\
\hline
\end{tabular}

also been made recently to extend the application of DFT-based quantum chemical and molecular dynamic simulations methods in order to understand the mechanism of adsorption of plant extract components on metal and alloys surfaces (Oguzie et al. 2013; Oguzie et al. 2010; Oguzie et al. 2012a; Umoren et al. 2014; Oguzie et al. 2012b; Obi-Egbedi et al. 2012). This is because the major criticism of the use of plant extract as corrosion inhibitor is often the inability to pinpoint which of the component(s) is/are actually responsible for the observed corrosion inhibition effect given that they are comprised of mixtures of organic compounds.

Although experimental studies on the application of AZI extract as a green corrosion inhibitors for different metals and alloys have been extensively reviewed in the work; the mechanism of interactions between the AZI extract component and the metal surfaces at the atomic level using molecular modeling studies is lacking and is still a matter of speculation. This difficulty can be tackled by the methodology of density functional theory and molecular dynamics simulations where selected DFT reactivity parameters of the individual major extracts components such as energy of the highest occupied molecular orbital $\left(E_{\mathrm{HOMO}}\right)$, energy of the lowest unoccupied molecular orbital $\left(E_{\mathrm{LUMO}}\right)$, energy band gap $(\Delta E)$, and the interaction energy between the extract components and the metal surface can be correlated with the corrosion inhibitive effect of the plant extract. According to the description of frontier orbital theory (ObiEgbedi et al. 2011), HOMO is often associated with the electron-donating ability of an inhibitor molecule. High $E_{\text {HOMO values }}$

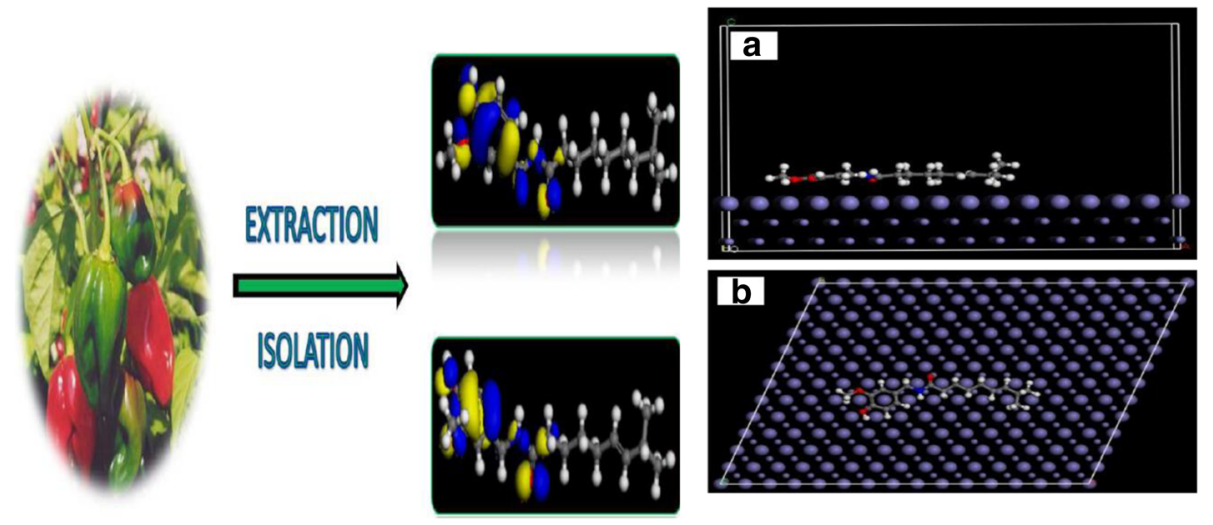

Fig. 2 Computational modeling of capsaicin and dihydrocapsaicin (the two main extract components of Capsicum frutescens) (Oguzie et al. 2013) 

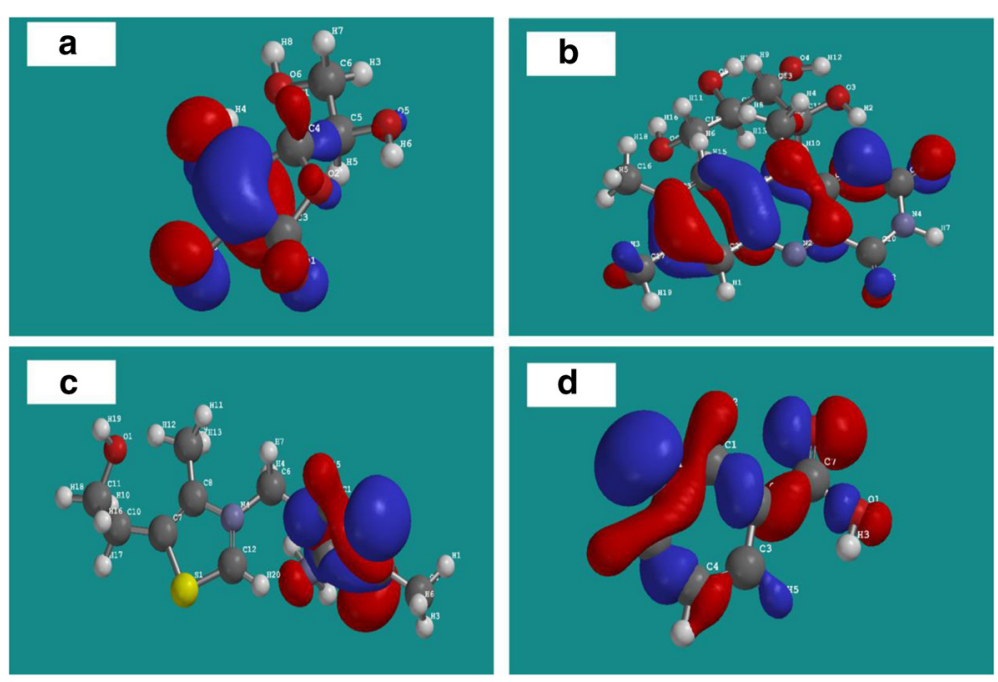

Fig. 3 The highest occupied molecular (HOMO) orbital density of a ascorbic acid, b riboflavin (RB), c thiamine (TH), and $\mathbf{d}$ nicotinic acid (NA) which constitute the main constituents of Spondias mombin extract (Obi-Egbedi et al. 2012)

indicate that the molecule has a tendency to donate electrons to the metal with unoccupied d orbitals. $E_{\mathrm{LUMO}}$ indicates the ability of the molecules to accept electrons (Obot and Obi-Egbedi 2010). The lower the value of $E_{\mathrm{LUMO}}$ of inhibitor molecule is, the easier its acceptance of electrons from the metal surface (Obot et al. 2009). The gap between the LUMO and HOMO energy levels of the inhibitor molecules is another important index, low absolute values of the energy band gap $\left(\Delta E=E_{\mathrm{LUMO}}-E_{\mathrm{HOMO}}\right)$ can indicate a good stability of the formed complex on the metal surface, therefore increasing the adsorption of a molecule on the metal surface (Xia et al. 2008). Some important reactivity parameters from DFT and molecular dynamics simulations (MDS) are summarized in Table 5. Also, Figs. 2 and 3 show examples of molecular modeling of major extract components from some plants used as corrosion inhibitors.

\section{Conclusions}

From the above discussion, it is quite obvious that AZI is an effective green corrosion inhibitor against various metals, especially for mild steel, aluminum, and tin. A lot of potential is still untapped especially computational modeling of the major extract components of AZI on different metal surfaces, and many other plant materials and should be further explored by researchers working in the area of corrosion science and engineering. This will help in the understanding of the adsorption mechanism and hence inhibition effect of plant extracts against metal corrosion. Also of importance is the exploration of AZI and other plant materials in other corrosive environment such as $\mathrm{CO} 2$ corrosion, $\mathrm{H} 2 \mathrm{~S}$ corrosion, and in cooling water systems.
Competing interests

The authors declare that they have no competing interests.

\section{Authors' contributions}

SKS, KM and IBO all contributed equally in this manuscript. All authors read and approved the final manuscript.

\section{Acknowledgements}

The author (AP) thankfully acknowledges the scholarship given by the president of the JECRC University for her PhD work.

\section{Author details}

${ }^{1}$ Green Chemistry and Sustainability Research Group, Department of Chemistry, JECRC University, Jaipur 303905, India. ${ }^{2}$ Centre of Research Excellence in Corrosion, King Fahd University of Petroleum and Minerals, Dhahran 31261, Kingdom of Saudi Arabia.

Received: 14 May 2015 Accepted: 21 September 2015

Published online: 09 October 2015

\section{References}

Abd-El-Nabey BA, Abdel-Gaber AM, Elawady GY, El-Houssein S (2012) Inhibitive action of some plant extracts on the alkaline corrosion of aluminum. Int J Electrochem Sci 7:7823-7839

Aboia KO, James O (2010) The effects of aloe vera extract on corrosion and kinetics of corrosion process of zinc in $\mathrm{HCl}$ solution. Corrosion Science 52(2):661-664

Ajanaku KO, Aladesuyi O, Ajanaku CO, Adedapo EA, Akiusiku AA, Sodiya FE (2015) Adsorption properties of Azadirachta indica extract on corrosion of aluminium in $1.85 \mathrm{M}$ hydrochloric acid. Journal of International Association of Advanced Technology and Science 16:4

Ajmal M, Mideen AS, Quraishi MA (1994) 2-Hydrazino-6-methyl-benzothiazole as an effective inhibitor for the corrosion of mild steel in acidic solutions. Corrosion Science Volume 36(1):79-84

Anozie IU, Akoma CS, Nnanna LA (2011) Corrosion inhibition of aluminium alloy in acidic medium by Euphorbia hirta and Dialum guineense extracts. Int J Pure Appl Sci Technol 6(2):79-88

Anuradha K, Vimala R, Narayanasamy B, Arockia JS, Rajendran S (2008) Corrosion inhibition of carbon steel in low chloride media by an aqueous extract of Hibiscus rosa-sinensis Linn. Chemical Engineering Communications 195:352-366

Arab TS, Turkustani-Al MA, Dhahiri-Al HR (2008) Synergistic effect of Azadirachta indica extract and iodide ions on the corrosion inhibition of aluminium in acid media. Journal of the Korean Chemical Society 52(3):281-294 
Avwiri O, Igho OF (2003) Inhibitive action of Vernonia amygdalina on the corrosion of aluminium alloys in acidic media. Material Letter 57:3705-3711

Ayssar N, Ideisan AA, Ibrahim AR, Maysoon A-K (2010) UAE neem extract as a corrosion inhibitor for carbon steel in $\mathrm{HCl}$ solution. International Journal of Corrosion 2010:1-9

Barton D. Comprehensive natural products chemistry. In: Meth-Cohn O, editor. Elsevier Science, Oxford: Newnes; 1999

Bentiss F, Traisnel M, Chaibi N, Mernari B, Vezin H, Lagrenée M (2002) 2,5-Bis(n-methoxyphenyl)-1,3,4-oxadiazoles used as corrosion inhibitors in acidic media: correlation between inhibition efficiency and chemical structure. Corrosion Science 44(10):2271-2289

Bhola SM, Alabbas FM, Rahul B, Spear JR, Mishra B, Olson DL, Kakporbia AE (2014) Neem extract as an inhibitor for biocorrosion influenced by sulfate reducing bacteria: a preliminary investigation. Engineering Failure Analysis 36:92-103

Buchweishaija J (2009) Phytochemicals as green corrosion inhibitors in various corrosive media: a review. J Sci 35:77-92

Chauhan LR, Gunasekaran G (2007) Corrosion inhibition of mild steel by plant extract in dilute $\mathrm{HCl}$ medium. Corrosion Science 49(3):1143-1161

Desai PS (2015a) Hibiscus rosa-sinensis (Jasud) leaves extracts used as corrosion inhibitors for mild steel in hydrochloric acid. E-jpmr 2(1):470-485

Desai PS (2015b) Azadirachta indica (neem) leaf extract used as corrosion inhibitors for mild steel in hydrochloric acid. GE-International Journal of Engineering Research 3(1):8-23

Ebenso EE, Udofot JJ, Ibok JU, Ekpe (1998) Studies on the inhibition of mild steel corrosion by some plant extracts in acidic medium. Discovery and Innovation 10(1-2):52-59

Ebenso EE, Ibok JU, Ekpe JU, Umeron S, Jackson E, Abiola K, Oforka CN, Martinez S (2004) Corrosion inhibition studies of some plant extracts on aluminium in acidic medium. Transactions-Society for the Advancement of Electrochemical Science and Technology 39(4):117-123

Ebenso EE, Kabanda MM, Arslan T, Saracoglu M, Kandemirli F, Murulana LC, Singh AK, Shukla SK, Hammouti B, Khaled KF (2012a) Quantum chemical investigations on quinoline derivatives as effective corrosion inhibitors for mild steel in acidic medium. Int J Electrochem Sci 7:5643-5676

Ebenso EE, Kabanda MM, Murulana LC, Singh AK, Shukla SK (2012b) Electrochemical and quantum chemical investigation of some azine and thiazine dyes as potential corrosion inhibitors for mild steel in hydrochloric acid solution. Ind Eng Chem Res 51:12940-12958

Eddy ON, Mamza PAP (2009) Inhibitive and adsorption properties of ethanol extract of seeds and leaves of Azadirachta indica on the corrosion of mild steel in $\mathrm{H}_{2} \mathrm{SO}_{4}$. Portugaliae Electrochimica Acta 27(4):443-456

El-hosary A, Saleh MR, Sharns MA (1972) Corrosion inhibition by naturally occurring substances-I. The effect of Hibiscus subdariffa (karkade) extract on the dissolution of Al and Zn. CorrosionSci 12:897-904

El-Sherif Rabab M, Badawy Waheed A (2011) Mechanism of corrosion and corrosion inhibition of tin in aqueous solutions containing tartaric acid. Int J Electrochem Sci 6:6469-6482

Gece G (2008) The use of quantum chemical methods in corrosion inhibitor studies. Corrosion Science 50(11):2981-2992

Gupta P, Jain G (2014) Corrosion inhibition by Aloe barbadensis (aloe vera) extract as green inhibitor for mild steel in $\mathrm{HNO}_{3}$. IJSRR 3(4):72-83

Jacobson. http://www.nap.edu/read/1924/chapter/5. 1986b

Jain R, Kotha A, Bhadu MK, Choudhary SK, Sairullah M, Rout AK, Rout TK (2014) Pickling inhibition efficiency of extracts of Azadirachta indica and Momordica charantia acidic medium on steel, Tata Search., pp 159-168

Jin L, Wang L, Chen D (2006) Corrosion inhibition of a hygroscopic inorganic dust depressor. J Univ Sci Technol 13:368-371

Kabanda MM, Ebenso EE (2012) Density functional theory and quantitative structure-activity relationship studies of some quinoxaline derivatives as potential corrosion inhibitors for copper in acidic medium. Int J Electrochem Sci 7:8713-8733

Kabanda MM, Murulana LC, Ozcan M, Karadag F, Dehri I, Obot IB, Ebenso EE (2012a) Quantum chemical studies on the corrosion inhibition of mild steel by some triazoles and benzimidazole derivatives in acidic medium. Int J Electrochem Sci 7:5035-5056

Kabanda MM, Murulana LC, Ebenso EE (2012b) Theoretical studies on phenazine and related compounds as corrosion inhibitors for mild steel in sulphuric acid medium. Int J Electrochem Sci 7:7179-7205

Kabanda MM, Obot IB, Ebenso EE (2013) Computational study of some amino acid derivatives as potential corrosion inhibitors for different metal surfaces and in different media. International Journal of Electrochemical Science 8:10839-10850.
Kliski'c M, Rado"sevi'c J, Gudi'c S S, Atalini'c V (2000) Aqueous extract of Rosmarinus officinalis $\mathrm{L}$. as inhibitor of Al-Mg alloy corrosion in chloride solution. Journal of Applied Electrochemistry 30(7):823-830

Kumar CSSR, Srinivas M, Yakkundi S (1996) Limonoids from the seeds of Azadirachta indica. Phytochemistry 43:451-455

Kumpawat N, Chaturvedi A, Upadhyay RK (2012) Comparative study of corrosion inhibition efficiency of naturally occurring ecofriendly varieties of holy basil (tulsi) for tin in $\mathrm{HNO}_{3}$ solution. Open Journal Of Metal 2(03):68-73

Linthorst JA (2010) An overview: origins and development of green chemistry. Foundations of Chemistry 12(1):55-68

Loto AC, Loto RT, Popoola API (2011) Effect of neem leaf (Azadirachta indica) extract on the corrosion inhibition of mild steel in dilute acids. International Journal of the Physical Sciences 6(9):2249-2257

Majeed MH, Sultan AA, Al-Sahlanee HH (2014) Corrosion inhibition of carbon steel in $1 \mathrm{M} \mathrm{HCl}$ solution by Ruta graveolens extract. J Chem Pharm Res 6(5):998

Mudhoo A, Sharma SK (2010) International Journal of Water Treatment and Green Chemistry 1(1):29-38

Muller B (2002) Corrosion inhibition of aluminium and zinc pigments by saccharides. Corros Sci 44:1583-1591

Nnanna LA, Obasi VU, Nwadiuko OC, Mejeh KI, Ekekwe ND, Udensi SC (2012) Inhibition by Newbouldia laevis leaf extract of the corrosion of aluminium in $\mathrm{HCl}$ and $\mathrm{H}_{2} \mathrm{SO}_{4}$ solutions. Archives of Applied Science Research 4(1):207-217

Noor EA (2007) Temperature effects on the corrosion inhibition of mild steel in acidic solutions by aqueous extract of fenugreek leaves. International Journal of Electrochemical Science 2:996-1017

ObiEgbedi NO et al (2011) Computational simulation and statistical analysis on the relationship between corrosion inhibition efficiency and molecular structure of some phenanthroline derivatives on mild steel surface. Int J Electrochem Sci 6:5649-5675

Obi-Egbedi NO, Obot IB, Umoren SA (2012) Spondias mombin L. as a green corrosion inhibitor for aluminium in sulphuric acid: correlation between inhibitive effect and electronic properties of extracts major constituents using density functional theory. Arabian Journal of Chemistry 5:361-373

Obiukwu OO, Opara OI, Oyinna CB (2013) Corrosion inhibition of stainless steel using plant extract Vernonia amygdalina and Azadirachta indica. The Pacific Journal of Science and Technology 14(2):31-35

Obot IB (2014) In: Aliofkhazraei M (ed) Developments in corrosion protection. INTECH, Croatia, pp 123-151

Obot IB, Gasem ZM (2014) Theoretical evaluation of corrosion inhibition performance of some pyrazine derivatives. Corrosion Science 83:359-366

Obot IB, Obi-Egbedi NO (2010) Adsorption properties and inhibition of mild steel corrosion in sulphuric acid solution by ketoconazole: experimental and theoretical investigation. Corrosion Science 52(1):198-204

Obot IB, Obi-Egbedi NO, Umoren SA (2009) The synergistic inhibitive effect and some quantum chemical parameters of 2,3-diaminonaphthalene and iodide ions on the hydrochloric acid corrosion of aluminium. Corrosion Science 51(2):276-282

Obot IB, Ebenso EE, Kabanda MM (2013) Metronidazole as environmentally safe corrosion inhibitor for mild steel in $0.5 \mathrm{M} \mathrm{HCl}$ : experimental and theoretical investigation. Journal of Environmental Chemical Engineering 1:431-439

Oguzie EE (2006) Adsorption and corrosion inhibitive properties of Azadirachta indica in acid solutions. Pigment and Resin Technology 35(6):334-340

Oguzie EE (2008) Evaluation of the inhibitive effect of some plant extracts on the acid corrosion of mild steel. Corrosion Science 50(11):2993-2998

Oguzie EE, Enenebeaku CK, Akalezi CO, Okoro SC, Ayuk AA, Ejike EN (2010) Adsorption and corrosion-inhibiting effect of Dacryodis edulis extract on low-carbon-steel corrosion in acidic media. Journal of Colloid and Interface Science 349:283-292

Oguzie EE, Adindu CB, Enenebeaku CK, Ogukwe CE, Chidiebere MA, Oguzie KL (2012a) Natural products for materials protection: mechanism of corrosion inhibition of mild steel by acid extracts of Piper guineense. Journal of Physical Chemical 116:13603-13615

Oguzie EE, Ogukwe CE, Ogbulie JN, Nwanebu FC, Adindu CB, Udeze IO, Oguzie KL, Eze FC (2012b) Broad spectrum corrosion inhibition: corrosion and microbial (SRB) growth inhibiting effects of Piper guineense extract. Journal of Material Science 47:3592-3601

Oguzie EE, Oguzie KL, Akalezi CO, Udeze IO, Ogbulie JN, Njoku VO (2013) Natural products for materials protection: corrosion and microbial growth inhibition using Capsicum frutescens biomass extracts. ACS Sustainable Chemistry and Engineering 1:214-225

Okafor PC, Uwah IE, Ekerenam OO, Ekpe UJ (2009) Combretum bracteosum extracts as eco-friendly corrosion inhibitor for mild steel in acidic medium. Pigment and Resin Technology 38(4):236-241 
Okafor PC, Ikpi ME, Ekanem UI, Ebenso EE (2013) Effects of extracts from Nauclea latifolia on the dissolution of carbon steel in $\mathrm{H}_{2} \mathrm{SO}_{4}$ solutions. Int J Electrochem Sci 8:12278-12286

Peter A, Sharma SK, Obot IB (2015) Use of natural gums as green corrosion inhibitors: an overview. International Journal of Industrial Chemistry 6(3):153-164

Quraishi AM, Ansari AF, Jamal D (2004) Corrosion inhibition of tin by some amino acids in citric acid. Indian Journal Or Chemical Technology 11:271-274

Quraishi MA, Obot IB, Eddy NO, Kabanda MM, Shukla SK, Singh AK, Murulana LC, Ebenso EE (2012) Electrochemical and quantum chemical studies on calmagite and fast sulphone black F dyes as corrosion inhibitors for mild steel in hydrochloric medium. Int J Electrochem Sci 7:8813-8831

Qurasishi AM (2004) NACE meeting papers

Raja PB, Sethuraman MG (2008a) Atropine sulphate as corrosion inhibitor for mild steel in sulphuric acid medium. Material Letters 62:1602-1604

Raja PB, Sethuraman MG (2008b) Natural products as corrosion inhibitor for metals in corrosive media-a review. Materials Letters 62(1):113-116

Rehan HH (2003) Corrosion control by water-soluble extracts from leaves of economic plants. Materialwissenschaft und Werkstofftechnik 34(2):232-237

Salami L, Wewe TOY, Akinyemi OP, Patinvoh RJ. A Study Of The Corrosion Inhibitor Of Mild Steel In Sulphuric Acid Using Musa Sapientum Peels Extract. Global Engineers \& Technologists Review. 2012; 2(12)

Sangeetha TV, Fredimoses M (2011) Inhibition of mild copper metal corrosion in $\mathrm{HNO}_{3}$ medium by acid extract of Azadirachta indica seed. E-Journal of Chemistry 8(S1):S1-S6

Sangeetha M, Rajendran S, Sathiyabama J, Prabhakar P (2012) Eco friendly extract of banana peel as corrosion inhibitor for carbon steel in sea water. J Nat Prod Plant Resour 2(5):601-610

Sanyal B (1981) Organic compounds as corrosion inhibitors in different environments - a review. Progress in Organic Coatings 9(2):165-236

Schaaf O, Jarvis AP, van der Esch SA, Giagnacovo G, Oldham NJ (2000) Rapid and sensitive analysis of Azadirachtin and related triterpenoids from neem (Azadirachta indica) by high-performance liquid chromatographyatmospheric pressure chemical ionization mass spectrometry. Journal of Chromatography A 886(1):89-97

Schmitt G, Hays GF, Burns W, Han EH, Pourbaix A, Jacobson G (2009a) World Corrosion Organization., pp 1-44

Schmitt G, Hays GF, Burns W, Han EH, Pourbaix A, Jacobson G (2009b) Global needs for knowledge dissemination, research, and development in materials deterioration and corrosion control., World Corrosion Organization 1-44

Sharma SK, Sharma A (2011) Green corrosion inhibitors: status in developing countries. In: Sharma SK (ed) Green corrosion chemistry and engineering. Wiley-VCH Publications, Germany, pp 157-176

Sharma SK, Mudhoo A, Khamis E (2009a) Corrosion inhibition of neem (Azadirachta indica) leaves extract as a green corrosion inhibitor for zinc in $\mathrm{H}_{2} \mathrm{SO}_{4}$. Journal of Corrosion Science and Engineering 11:1-25

Sharma SK, Jain G, Sharma J, Mudhoo A, Sharma J (2009b) RASAYAN. Journal of Chemistry 2 2:332-339

Sharma SK, Mudhoo A, Jain G, Khamis E (2009c) Gray chemistry verses green chemistry: challenges and opportunities. Green Chemistry Letters and Reviews 2(1):47-51

Sharma SK, Mudhoo A, Zhang W (2010a) Green chemistry and engineering: a versatile research perspective. In: Sharma SK, Mudhoo A (eds) Green chemistry for environmental sustainability, vol 1. Taylor \& Francis Group, LLC, Florida, Boca Raton, pp 1-52

Sharma SK, Jain G, Sharma J, Mudhoo A (2010b) Journal of the Indian Council of Chemists 27(1):35-39

Sharma SK, Jain G, Sharma J, Mudhoo A (2010c) Corrosion inhibition behaviour of Azadirachta indica (neem) leaves extract as a green corrosion inhibitor for zinc in hydrochloric acid: a preliminary study. International Journal of Applied Chemistry 6(1):83-94

Sharma SK, Mudhoo A, Jain G, Sharma J (2010d) Corrosion inhibition and adsorption properties of Azadirachta indica mature leaves extract as green inhibitor for mild steel in $\mathrm{HNO}_{3}$. Green Chemistry Letters and Reviews 3(1):7-15

Sharma SK, Sanghi Rashmi, Singh Vandana (2011) Environment and the role of green chemistry. In: Sanghi R (ed) Green chemistry for environmental remediation. Scrivener Publishing LLC, Massachusetts, pp 3-34

Sharma A, Choudhary G, Sharma A, Yadav S (2013) Effect of temperature on inhibitory efficacy of Azadirachta indica fruit on acid corrosion of aluminum. International Journal of Innovative Research in Science Engineering and Technology 2(12):7982-7992
Shyamala M, Arulanantham A (2009) Eclipta alba as corrosion pickling inhibitor on mild steel in hydrochloric acid. Journal of Materials Science and Technology 25(5):633-636

Singh A, Kumar A, Pramanik T (2013) A theoretical approach to the study of some plant extracts as green corrosion inhibitor for mild steel in $\mathrm{HCl}$ solution. Oriental Journal of Chemistry 29(1):277-283

Souza TF, Magalhães M, Torres W, D'Elia E (2015) Inhibitory action of ilex paraguariensis extracts on the corrosion of carbon steel in $\mathrm{HCl}$ solution. Int J Electrochem Sci 10:22-33

Subhashini S, Rajalakshmi R, Prithiba A, Mathina A (2010) Corrosion mitigating effect of Cyamopsis tetragonoloba seed extract on mild steel in acid medium. E-Journal of Chemistry 7(4):1133-1137

Thompson NG, Yunovich M, Dunmire D (2007) Cost of corrosion and corrosion maintenance strategies. Corrosion Reviews 25(3-4):247-262

Tuaweri TJ, Ogbonnaya EA, Onyemaobi OO (2015) Corrosion inhibition of heat treated mild steel with neem leave extract in a chloride medium. International Journal of Research in Engineering and Technology 04(6):2321-7308

Ulaeto SB, Ekpe UJ, Chidiebere MA, Oguzie EE (2012) Corrosion inhibition of mild steel in hydrochloric acid by acid extracts of Eichhornia crassipes. International Journal of Materials and Chemistry 2(4):158-164

Umoren SA, Eduok UM, Israel AU, Obot IB, Solomon MM (2012) Coconut coir dust extract: a novel eco-friendly corrosion inhibitor for $\mathrm{Al}$ in $\mathrm{HCl}$ solutions. Green Chemistry Letters and Reviews 5(3):303-313

Umoren S, Obot IB , Gasem Z, Odewunmi NA. Experimental and theoretical studies of red apple fruit extract as green corrosion inhibitor for mild steel in $\mathrm{HCl}$ solution. Journal of Dispersion Science and Technology (just-accepted). 2014

Vasudha VG, Saratha R (2011) Studies on inhibition of acid corrosion of mild steel by Terminalia catappa (tropical almond) leaves. Orient J Chem 27(3):1165-1171

Xia S, Qiu M, Yu L, Liu F, Zhao H (2008) Molecular dynamics and density functional theory study on relationship between structure of imidazoline derivatives and inhibition performance. Corrosion Science 50:2021-2029

Yamuna J, Athony N (2014) Citrus sinensis L. leaf extract as an efficient green corrosion inhibitor for mild steel in aqueous medium. International Journal of ChemTech Research 7(01):37-43

Yetri Y, Emriadi, Jamarun N, Gunawarman (2014) Corrosion inhibition efficiency of mild steel in hydrochloric acid by adding Theobroma cacao peel extract. International conference on biological, chemical and environmental sciences Penang (Malaysia)

\section{Submit your manuscript to a SpringerOpen ${ }^{\odot}$ journal and benefit from:}

- Convenient online submission

$\checkmark$ Rigorous peer review

- Immediate publication on acceptance

- Open access: articles freely available online

- High visibility within the field

- Retaining the copyright to your article

Submit your next manuscript at $>$ springeropen.com 